\title{
Site Specific Nutrient Management of Cassava Improves Soil Quality
}

\author{
Madhavi Baiju $^{1 *}$, S. Sreelekha ${ }^{1}$, R. Shiny ${ }^{2}$, S. S. Veena ${ }^{2}$ and G. Byju ${ }^{2}$ \\ ${ }^{1}$ National College, Manacaud, Thiruvananthapuram, Kerala, India \\ ${ }^{2}$ ICAR-Central Tuber Crops Research Institute, Sreekariyam, \\ Thiruvananthapuram, Kerala, India \\ *Corresponding author
}

\section{Keywords}

Cassava, Site specific nutrient management, Minimum data set, Soil quality index

\section{Article Info}

Accepted: 07 November 2020 Available Online: 10 December 2020

\section{A B S T R A C T}

Cassava (Manihot esculenta Crantz) is an important staple crop for the rural population worldwide and is used for many other purposes too, especially as an industrial crop. Sustainable intensification of cassava has become necessary as it has now an everincreasing role as a food security crop in the changing climate scenario. In this context, development of site specific nutrient management (SSNM) of cassava based on the modified QUEFTS model assumes greater importance and the performance of SSNM with regard to its influence on soil quality needs to be assessed. Hence a study was conducted in a 12 year continuous SSNM experimental field to study its effect on soil quality. Soil $\mathrm{pH}$, labile carbon, available calcium and available zinc were found to significantly contribute to soil quality index (SQI). Significantly higher SQI was observed in SSNM plot (0.85) followed by present recommendation (PR) plot (0.81), which were on par and significantly lower SQI values were observed in nutrient omission plots with the lowest value being recorded in $\mathrm{P}$ omission plot (0.62). The contribution of the minimum data set (MDS) indicators (scored and weighed) to the overall index value in each treatment showed that labile carbon contributed the maximum in all treatments studied. The per cent contribution of labile carbon to SQI was 28 per cent in SSNM plot. The study showed an improvement in soil quality in SSNM plot compared to present recommendation plot.

\section{Introduction}

Cassava (Manihot esculenta Crantz) is grown in 104 countries in a total area of $24.6 \mathrm{~m}$ ha of land producing $277.8 \mathrm{~m}$ tons of tuber making it the fifth most important food crop after maize (1148 $\mathrm{m}$ tons), rice ( $782 \mathrm{~m}$ tons), wheat (734 $\mathrm{m}$ tons) and potato (368 $\mathrm{m}$ tons) (http://www.fao.org). It is an important staple crop for the rural population worldwide and is used for many other purposes too, especially as an industrial crop. It is an extensively cultivated crop for its edible storage root which is rich in starch and high energy content of about $16.5 \mathrm{MJ} \mathrm{kg}^{-1}$ dry matter (Montagnac et al., 2009).

Sustainable intensification of cassava has, therefore, become necessary as it has now an ever-increasing role as a food security crop in the changing climate scenario (Sabitha and Byju, 2016) for three important reasons. First, 
it is a food security crop for about 800 million people worldwide (FAO, 2013) but is also increasingly supporting a growing industry for production of starch, sago and other products. Second, cassava is well known for its drought tolerance and performance under marginal soil conditions. Drought tolerance is due to its stomatal sensitivity to changes in atmospheric humidity and soil water, deeper rooting capacity of more than two meter and ability to reduce leaf canopy so that crop water consumption is reduced. Third, cassava has a large potential productivity due to higher net photosynthetic rate, higher radiation and water use efficiencies. The high net photosynthetic rate is primarily due to $\mathrm{C} 4$ C3 intermediate photosynthetic pathway with 15-25 per cent activity of the C4 enzyme, phospho enol pyruvate carboxylase (PEPC). The crop has a higher radiation use efficiency of 1.5-2.3 gram of dry matter per MJ of intercepted light and hence a large potential productivity. It also has a large water use efficiency of 2.9-gram dry matter per $\mathrm{kg}$ of water transpired or 0.4-4.8-gram dry matter per $\mathrm{kg}$ water evapotranspiration. Under high humidity, wet soil, high leaf temperature and higher solar radiation, the net photosynthetic rate of cassava exceeds $40 \mu \mathrm{mol} \mathrm{m} \mathrm{m}^{-2} \mathrm{~s}^{-1}$ whereas for rice it is $20 \mu \mathrm{mol} \mathrm{m} \mathrm{m}^{-2} \mathrm{~s}^{-1}$. High leaf photosynthetic potential, long leaf life of more than 60 days, sustainable leaf canopy that optimises photon interception during a significant portion of growth cycle and a high harvest index of above 5 are also the reasons for large potential productivity (El-Sharkawy, 2012). In this context, more knowledge intensive, model based nutrient recommendations became inevitable in order to better accurately assess the wide yield gap. Site specific nutrient management (SSNM) of cassava based on the modified QUEFTS model has been developed to determine potential and economic yields in different agro-ecologies for agro-advisory purposes and is gaining importance worldwide (Byju et al., 2012; Ezui et al., 2017; Adiele et al., 2020). Such modified QUEFTS model-based recommendations have been developed for at least a dozen important food crops in the recent past that shows that it is a strong tool that captures the major patterns of crop yield response to fertilizer and interactions between $\mathrm{N}, \mathrm{P}$ and $\mathrm{K}$ dependent on inherent soil fertility (Remya Remesh and Byju, 2018).

Studies on SSNM worldwide on different crops showed that the new concept could achieve the target yield with minimum required nutrients so that nutrient use efficiency and farm income could also be enhanced with minimum fertilizer pollution to the environment. But its impact on soil quality has to be assessed based on the concept developed by different workers (Karlen et al., 2003; Letey et al., 2003). Soil quality cannot be measured directly, but soil properties that are sensitive to changes in management can be used as indicators (Andrews et al., 2004). Soil quality assessments are thus used to evaluate the effect of management on the health of the soil and it will benefit crop land productivity without affecting factor productivity and environmental impact. Hence the present study was aimed at understanding the effect of balanced fertilizer application by site specific nutrient management (SSNM) of cassava in an Ultisols on soil quality.

\section{Materials and Methods}

\section{Field experiment}

The study was conducted at ICAR-Central Tuber Crops Research Institute (ICARCTCRI), Sreekariyam, Thiruvananthapuram, Kerala during 2019-2020. Soil samples for the soil quality assessments were taken from a 12-year SSNM experimental field in the farm which was subjected to the continuous fertilizer treatments since 2008. The six 
treatments and 4 replications per treatment were laid out in a randomized completed block design (RCBD). The treatments include a nitrogen omission plot $(0 \mathrm{~N})$, phosphorus omission plot (0P), potassium omission plot $(0 \mathrm{~K})$, nitrogen, phosphorus and potassium omission plot (0NPK), site specific nutrient management (SSNM plot) and present recommendation (PR) plot. Plot size was 5.4 $\mathrm{m} \times 5.4 \mathrm{~m}$ and the setts were planted on mounds at a spacing of $90 \times 90 \mathrm{~cm}$. The cassava variety, Sree Vijaya, a high yielding, short duration one with very good cooking quality which was released from ICARCTCRI was used for the experiment. All other soil and crop management practices were followed uniformly as per Nair et al., (2004). Table 1 gives a detailed description of the different treatments used for the study.

\section{Soil physico-chemical properties}

Soil samples for the study were taken at the time of harvest to a depth of $15 \mathrm{~cm}$. A portion of the soil samples were air dried and sieved through a $2 \mathrm{~mm}$ sieve before physical and chemical analysis and another portion of fresh soil samples were refrigerated and used for biochemical and biological analysis. Bulk density was determined by using Keen Raczkowskii box method (Wright, 1939). Soil $\mathrm{pH}$ was measured using 1:2.5 soil: water suspension using $\mathrm{pH}$ meter (Page et al., 1982). Organic carbon was determined by dichromate oxidation method (Walkley and Black, 1934). Labile carbon was determined by permanganate method (Weil et al., 2003). In this method slightly alkaline $\mathrm{KMnO}_{4}$ reacts with the most readily oxidizable (active) forms of soil carbon, converting Mn (VII) to $\mathrm{Mn}$ (II) and proportionally lowering absorbance of $550 \mathrm{~nm}$ light. Available N, P and $\mathrm{K}$ were estimated based on the procedures outlined by Byju (2012). Available $\mathrm{Ca}$ and $\mathrm{Mg}$ present in the soil were extracted with neutral $1 \mathrm{~N}$ ammonium acetate and the $\mathrm{Ca}$ and
$\mathrm{Mg}$ concentrations were determined using Perkin Elmer PinAAcle $900 \mathrm{H}$ model atomic absorption spectrometer (Page et al., 1982). Contents of available $\mathrm{Fe}, \mathrm{Mn}, \mathrm{Zn}$ and $\mathrm{Cu}$ were estimated using $0.1 \mathrm{~N} \mathrm{HCl}$ extract (Lindsay, 1995).

\section{Soil biochemical properties}

Urease (urea amino hydrolase) is the enzyme that catalyses the hydrolysis of urea to $\mathrm{CO}_{2}$ and $\mathrm{NH}_{3}$. The method used for estimation of the rate of urea hydrolysis in soils involves colorimetric determination of the urea remaining after incubation of soil with the urea solution for $24 \mathrm{hrs}$ at $30^{\circ} \mathrm{C}$ (Gosewinkel and Broadbent, 1984). The amount of urea hydrolysed $\left(\mathrm{g}^{-1}\right.$ of the soil $\left.\mathrm{h}^{-1}\right)$ is estimated from the difference between the initial amount of urea added and that recovered after incubation. The dehydrogenase activity in soil was estimated using the method of Casida et al., (1964). The method based on extraction with ethanol and colorimetric determination of the triphenyl formazan (TPF) produced from the reduction of 2, 3, 5-triphenyl tetrazolium chloride (TTC) in soils. Phosphatase activity was determined using the method of Tabatabi and Bremner (1969). This method is based on the release of $p$ nitrophenol released by phosphatase activity when the soil is incubated with buffer sodium p- nitrophenyl phosphate, sodium and toluene.

\section{Soil quality index}

Data were processed using SAS statistics programme and XLSTAT. Eighteen soil parameters were measured and the data were first checked for normality and then subjected to univariate analysis of variance (ANOVA). Variables with $\mathrm{F}$ statistically significant at $\mathrm{p}<$ 0.05 were further analysed by Principal Component analysis (PCA). The PCA is a mathematical procedure that gives a small number of uncorrelated variables or principal 
components (PCs) from several correlated and thus it can reduce the size of the parameter data set. The first PC accounts for most of the remaining variability. It is assumed that PCs receiving high eigenvalues best represents variation in the systems. Therefore, only the PCs with eigenvalues more than one and those that explain at least 30 percent of the variation in data was included (Kaiser, 1960).

Under a particular PC each soil property was given a weight or factor loading that represents the contribution of the variable to the composition of the PC. Within each PC, only highly weighted factors were retained for minimum data set (MDS). Highly weighted factor loadings were defined as those having absolute values within 10 percent of highest factor loading. After determining the MDS indicators, they were grouped into three groups to determine the shape of the decision function. The shape of the decision function was determined by expert knowledge and literature values quantifying the relationships between indicators and soil functioning. An upper asymptote or 'more is better' functions are considered (Soil Survey Staff, 1988). Once transformed, the indicators were weighted by the PCA results. Each PC explained a certain amount (percent) of the variation in the total data set. This percentage divided by the total percentage of variation explained by all PCs with eigenvectors higher than one, provided weighting factor for variables chosen under a given PC. The weighted MDS variable scores were then summed for each observation in the following formula,

$\mathrm{SQI}=\sum \mathrm{Wi} \times \mathrm{Si}$

where $\mathrm{W}$ is the $\mathrm{PC}$ weighting factor and $\mathrm{S}$ is the indicator score. The calculated SQI treatment means were compared using ANOVA. It is assumed that higher index scores meant better soil quality or greater performance of soil function.

\section{Results and Discussion}

\section{Correlation matrix of soil physico-chemical and biochemical properties}

Correlation matrix of various soil properties are shown in Table 2. The soil $\mathrm{pH}$ shows significantly positive correlation with organic carbon (0.35), $\mathrm{P}(\mathrm{r}=0.43), \mathrm{Ca}(\mathrm{r}=0.66), \mathrm{Mg}(\mathrm{r}$ $=0.46), \mathrm{Zn}(\mathrm{r}=0.40)$ and $\mathrm{LC}(\mathrm{r}=0.48)$. The OC shows significantly positive correlation with $\mathrm{P}(\mathrm{r}=0.41), \mathrm{Zn}(\mathrm{r}=0.45)$, and LC $(\mathrm{r}=$ $0.68)$. The $\mathrm{N}$ shows significantly positive correlation with $\mathrm{P}(\mathrm{r}=0.41)$ and $\mathrm{Ca}(\mathrm{r}=0.49)$. The $\mathrm{P}$ shows significantly positive correlation with $\mathrm{Ca}(\mathrm{r}=0.66), \mathrm{Mg}(\mathrm{r}=0.40), \mathrm{Zn}(\mathrm{r}=$ $0.49)$ and $\mathrm{LC}(\mathrm{r}=0.52)$. The $\mathrm{K}$ shows significantly positive correlation with $\mathrm{Cu}(\mathrm{r}=$ 0.41 ) and significantly negative correlation with $\mathrm{Mg}(\mathrm{r}=-0.46)$. The $\mathrm{Ca}$ shows significantly positive correlation with $\mathrm{Mg}(\mathrm{r}=$ $0.65), \mathrm{Zn}(\mathrm{r}=0.44)$ and $\mathrm{LC}(\mathrm{r}=0.48)$. The Fe shows significantly positive correlation with $\mathrm{Zn}(\mathrm{r}=0.62)$, LC $(\mathrm{r}=0.48)$ and shows significantly negative correlation with phosphatase activity $(\mathrm{r}=-0.45)$. The dehydrogenase activity shows significantly positive correlation with bulk density $(\mathrm{r}=$ 0.69 ).

\section{Principal component analysis}

The effect of different treatments on soil quality was evaluated by computing soil quality index (SQI). The soil parameters which showed significant difference among the treatments were selected for principal component analysis (PCA).

Considering the previously mentioned soil characteristics four principal components (PCs) were generated using the principal component analysis (Table 3 ).

Eigen values highlighted in bold correspond to the PCs examined for the index. Based on Kasier (1960) criterion, the number of 
datasets to retain was up to $\mathrm{PC} 1$. The eigen value started to be lower than 1 from PC1 onwards. This PCs explained 64.20 per cent of the total variance and the residual components gave a very small contribution to the variance. The PC1, PC2, PC3 and PC4 explained 64.20, 19.07, 8.69 and 8.03 per cent of the total respectively.

\section{Soil quality index}

After nonlinear scoring of the parameter values selected from PCA above, the soil quality index was calculated. The final normalised SQI based soil quality equation is:

Normalised SQI = $1(\mathrm{SpH}+\mathrm{SLC}+\mathrm{Ca}+\mathrm{Zn}) / 4$

Table 4 and Figure 1 show the values of normalised cumulative soil quality indices for weighted MDS variable scores for the various treatments.
The normalised cumulative SQI values for the various treatments showed significant differences among the treatments. A significantly higher soil quality index was observed for SSNM plot (0.85) followed by PR plot (0.81), which were on par and significantly lower SQI values were observed in nutrient omission plots with the lowest value recorded in $\mathrm{P}$ omission plot (0.62). The present recommendation plot had SQI on par with SSNM plot which may due to the reason that the blanket recommendation was developed based on field experiments conducted at the same farm years ago and the target yield fixed for SSNM was $30 \mathrm{t} \mathrm{ha}^{-1}$.

Figure 2 shows the contribution of the MDS indicators (scored and weighed) to the overall index value in each treatment. The contribution of labile carbon to the SQI was found to be highest in all the treatments. Zinc contributed lowest percentage in $\mathrm{P}$ omission plot $(0.47 \%)$ and NPK omission $(0.48 \%)$.

Table.1 Description of different treatments used for the study

\begin{tabular}{|c|c|c|c|}
\hline & \multicolumn{3}{|c|}{ Nutrient rates $\left(\mathrm{kg} \mathrm{ha}^{-1}\right)$} \\
\hline Treatment & $\mathrm{N}$ & $\mathrm{P}_{2} \mathrm{O}_{5}$ & $\mathrm{~K}_{2} \mathrm{O}$ \\
\hline 0N-Nitrogen omission plot & 0 & 75 & 150 \\
\hline 0P-Phosphorus omission plot & 150 & 0 & 150 \\
\hline 0K-Potassium omission plot & 150 & 75 & 0 \\
\hline 0NPK-NPK omission plot & 0 & 0 & 0 \\
\hline $\begin{array}{l}\text { Present recommendation (PR) } \\
\text { plot }\end{array}$ & 100 & 50 & 100 \\
\hline $\begin{array}{l}\text { Site } \quad \text { specific } \\
\text { management }(\text { SSNM) } \\
\text { plot }\end{array}$ & \multicolumn{3}{|c|}{$\begin{array}{l}\text { Secondary }(\mathrm{Ca}, \mathrm{Mg} \text { ) and micronutrient (Fe, } \mathrm{Mn} \text {, } \\
\mathrm{Zn}, \mathrm{Cu})- \text { inclusive customised fertilizer } \\
\text { formulation developed for agro ecological unit } \\
(\mathrm{AEU}) 8 \text { of Kerala state (Byju et al., 2016) }\end{array}$} \\
\hline
\end{tabular}


Table.2 Correlation matrix of soil physico-chemical and biological properties at harvest

\begin{tabular}{|c|c|c|c|c|c|c|c|c|c|c|c|c|c|c|c|c|}
\hline Parameter & $\mathrm{pH}$ & $\mathrm{OC}$ & $\mathrm{N}$ & $\mathrm{P}$ & K & $\mathrm{Ca}$ & $\mathrm{Mg}$ & $\mathrm{Fe}$ & $\mathrm{Mn}$ & $\mathrm{Zn}$ & $\mathrm{Cu}$ & LC & Urease & Dehydrogenase & Phosphatase & $\begin{array}{l}\text { Bulk } \\
\text { density }\end{array}$ \\
\hline pH & 1 & & & & & & & & & & & & & & & \\
\hline OC & $0.35^{*}$ & 1 & & & & & & & & & & & & & & \\
\hline $\mathbf{N}$ & 0.14 & -0.06 & 1 & & & & & & & & & & & & & \\
\hline $\mathbf{P}$ & $0.43 *$ & $0.41 *$ & $0.42 *$ & 1 & & & & & & & & & & & & \\
\hline $\mathbf{K}$ & 0.30 & 0.12 & 0.07 & 0.03 & 1 & & & & & & & & & & & \\
\hline $\mathbf{C a}$ & $0.66^{*}$ & 0.20 & $0.49 *$ & $0.66^{*}$ & -0.02 & 1 & & & & & & & & & & \\
\hline Mg & $0.46^{*}$ & 0.06 & -0.07 & $0.40^{*}$ & -0.42 & $0.65^{*}$ & 1 & & & & & & & & & \\
\hline $\mathbf{F e}$ & 0.07 & 0.21 & 0.21 & -0.06 & 0.04 & 0.22 & -0.11 & 1 & & & & & & & & \\
\hline Mn & 0.01 & -0.33 & 0.12 & -0.17 & -0.17 & 0.11 & 0.09 & 0.09 & 1 & & & & & & & \\
\hline Zn & $0.40 *$ & $0.45^{*}$ & 0.31 & $0.49^{*}$ & 0.21 & $0.44 *$ & -0.04 & $0.62 *$ & -0.02 & 1 & & & & & & \\
\hline $\mathrm{Cu}$ & 0.12 & 0.13 & 0.17 & 0.14 & $0.41 *$ & 0.22 & 0.00 & 0.15 & -0.11 & 0.16 & 1 & & & & & \\
\hline LC & $0.48 *$ & $0.68 *$ & 0.24 & $0.52 *$ & 0.24 & $0.49 *$ & 0.07 & $0.43 *$ & -0.38 & $0.66^{*}$ & 0.15 & 1 & & & & \\
\hline Urease & 0.04 & 0.10 & -0.20 & -0.07 & 0.20 & -0.14 & -0.21 & 0.10 & 0.18 & 0.06 & 0.24 & 0.03 & 1 & & & \\
\hline Dehydrogenase & 0.30 & 0.25 & 0.01 & 0.17 & -0.20 & 0.21 & 0.08 & -0.06 & 0.01 & 0.10 & 0.03 & 0.25 & 0.08 & 1 & & \\
\hline Phosphatase & -0.02 & -0.19 & -0.01 & 0.17 & -0.38 & 0.30 & $0.64^{*}$ & -0.45 & 0.03 & -0.50 & -0.14 & -0.14 & -0.33 & -0.08 & 1 & \\
\hline Bulk density & 0.22 & 0.09 & $0.11+$ & -0.04 & -0.19 & 0.13 & 0.03 & 0.05 & 0.14 & 0.00 & 0.01 & 0.05 & -0.09 & $0.69 *$ & -0.06 & 1 \\
\hline
\end{tabular}


Table.3 Results of principal component analysis of soil quality indicators for the first four PCs selected for computing soil quality index

\begin{tabular}{|l|c|c|c|c|}
\hline Principal components & PC1 & PC2 & PC3 & PC4 \\
\hline Eigen value & $\mathbf{2 . 5 7}$ & 0.76 & 0.35 & 0.32 \\
\hline Loading factor & 1 & - & - & - \\
\hline Percent & 64.20 & 19.07 & 8.69 & 8.03 \\
\hline Cumulative Percent & 64.20 & 83.27 & 91.97 & 100 \\
\hline Eigen vectors & & & & \\
\hline Soil pH & $\mathbf{0 . 5 0}$ & -0.52 & -0.53 & -0.45 \\
\hline LC & $\mathbf{0 . 5 1}$ & 0.43 & -0.45 & 0.60 \\
\hline Ca & $\mathbf{0 . 5 0}$ & -0.47 & 0.62 & 0.37 \\
\hline Zn & $\mathbf{0 . 4 9}$ & 0.57 & 0.36 & -0.55 \\
\hline
\end{tabular}

Table.4 Normalised cumulative soil quality indices for different treatments

\begin{tabular}{|l|c|}
\hline Treatment & Normalised SQI \\
\hline N omission & 0.72 \\
\hline P omission & 0.62 \\
\hline K omission & 0.73 \\
\hline NPK omission & 0.74 \\
\hline PR & 0.81 \\
\hline SSNM & 0.85 \\
\hline LSD $(\mathbf{0 . 0 5})$ & 0.06 \\
\hline
\end{tabular}

Fig.1 Effect of different fertilizer treatment on soil quality index (SQI)

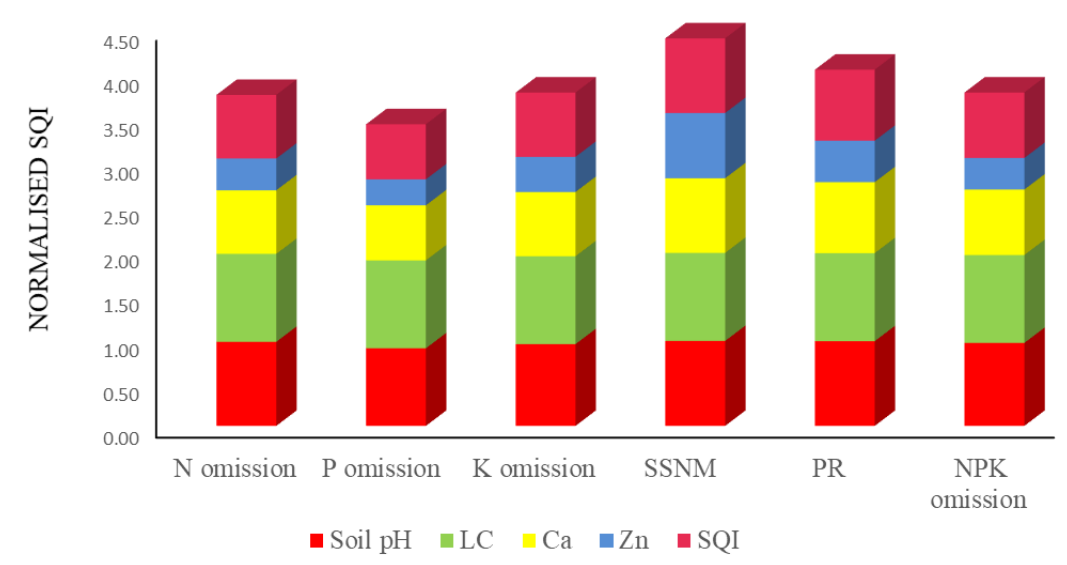


Fig.2 Percentage of contribution of indicators to soil quality

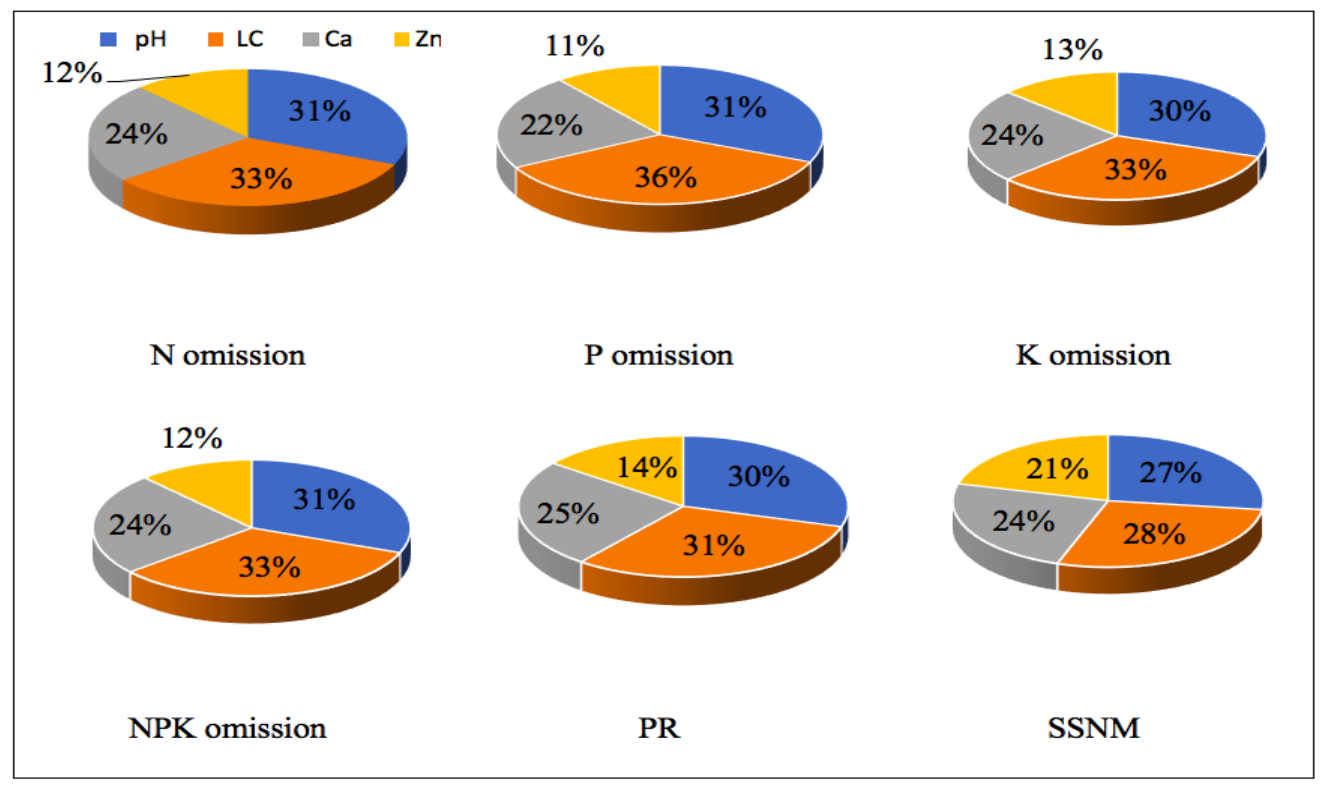

In $\mathrm{N}$ omission plot highest percentage of contribution to soil quality index was shown by labile carbon (33\%) and lowest by zinc $(12 \%)$. In $\mathrm{P}$ omission plot the highest percentage of contribution to soil quality index was shown by labile carbon (36\%) and lowest by zinc (11\%). In K omission plot the highest percentage of contribution of soil quality index was shown by labile carbon (33\%) and lowest by zinc (13\%). In NPK omission plot the highest percentage of contribution of soil quality index was shown by labile carbon (33\%) and lowest by zinc $(12 \%)$. In PR plot the highest percentage of contribution of soil quality index was shown by labile carbon (31\%) and lowest by zinc (14\%). In SSNM plot the highest percentage of contribution of soil quality index was shown by labile carbon (28\%) and lowest by zinc (21\%).

This study demonstrated how the proposed soil quality assessment framework can be used to assess the impact of nutrient management options on soil quality. This will help us to assess soil management problems that need to be addressed to sustain or improve our soil resources without sacrificing yield.

\section{References}

Adiele, J.G., A.G.T. Schut, R.P.M. van der Beuken, K.S. Ezui, P. Pypers, A.O. Ano, C.N. Egesi and K.E. Giller. 2020. Towards closing the cassava yield gap in West Africa: agronomic efficiency and storage root responses to NPK fertilizers. Field Crops Res. 253: https://doi.org/10.1016/j.fcr.2020.107820

Andrews, S.S., D.L. Karlen, and C.A. Cambardella. 2004. The soil management assessment framework: A quantitative soil quality evaluation method. Soil Sci. Soc. Am. J. 68:1945-1962.

Byju G., M. Nedunchezhiyan, A.C. Hridya and Sabitha Soman. 2016. Site-specific nutrient management for cassava in southern India. Agronomy Journal 108: 830-840.

Byju, G., M. Nedunchezhiyan, C.S. Ravindran, V.S. Santhosh Mithra, V. Ravi, and S.K. Naskar. 2012. Modeling the response of cassava to fertilizers: A site specific nutrient management approach for higher 
tuberous root yield. Commun. Soil Sci. Plant Anal. 43:1149-1162

Byju, G., Nedunchezhiyan, M., Ramanandam, G., 2010. Soil fertility research for cassava in India. In: CIAT (Ed.), A New Future for Cassava in Asia: Its Use as Food, Feed and Fuel to Benefit the Poor. Proc. 8th Regional Workshop, Vientiane, LaoPDR, 20-24 October, 2008. CIAT, Cali, Colombia, pp. 275-297.

El-Sharkawy, M.A. 2012. Stress-tolerant cassava: the role of integrative ecophysiology-breeding research in crop improvement. Open Journal of Soil Science 2: 162-186.

Ezui, K., A. Franke, B. Ahiabor, F. Tetteh, J. Sogbedji, B. Janssen, A. Mando and and K. Giller. 2017. Understanding cassava yield response to soil and fertilizer nutrient supply in West Africa. Plant Soil 420: 331-347.

FAO. 2013. Save and grow: cassava. A guide to sustainable production intensification. FAO, Rome, Italy.

FAOSTAT (2018). FAO Market development and outlook, "Production/Crops cassava, November year 2018”. http://www.fao.org

Kaiser, H.F. 1960. The application of electronic computers to factor analysis. Educ. Psychol. Meas. 29: 141-151.

Karlen, D.L., J.W. Doran, B.J. Weinhold, and S.S. Andrews. 2003. Soil quality: Humankind's foundation for survival. J. Soil Water Conserv. 58:171-179.

Letey, J., R.E. Sojka, D.R. Upchurch, D.K. Cassel, K.R. Olson, W.A. Payne, S.E. Petrie, G.H. Price, R.J. Reginato, H.D. Scott, P.J. Smethurst, and G.B. Triplett.
2003. Deficiencies in the soil quality concept and its application. J. Soil Water Conserv. 58:180-187.

Nair, G.M., S. Ramanathan, and T. Asokan Nambiar. 2004. Agrotechaniques of tuber crops. CTCRI, Thiruvananthapuram, Kerala, India

Page, A.L., R.H. Miller, and D.R. Keeney. 1982. Methods of soil analysis. Part 2. Chemical and microbiological properties. Agronomy Series No. 9, ASA, SSSA, Madison Winconsin, USA.

Remya Remesh and Byju, 2018, Journal of Root Crops, 2018, Vol. 44 No. 1, pp. 1927 Indian Society for Root Crops. ISSN 0378-2409, ISSN 2454-9053 (online)

Sabitha, S., Byju, G., Sreekumar, J., 2016. Projected changes in mean temperature and total precipitation and climate suitability of cassava (Manihot esculenta Crantz) in major growing environments of India. Indian J. Agric. Sci. 86 (5), 647653

Walkley, A., and I.A. Black. 1934. An examination of the degtjareff method for determining soil organic matter and a proposed modification of the chromic acid titration method. Soil Sci. 37: 29-38.

Weil, R.R., K.R. Islam, M.A. Stine, J.B. Gruver, and S.E.S. Liebig. 2003. Estimating active carbon for soil quality assessment: a simplified method for laboratory and field use. Am. J. Altern. Agric. 18(1): 3-17

Wright, C.H. 1939. Troells method by using Keen-Raczkowskii Box. In C.H Wright (ed.). Soil analysis. Thomas Murby and Co.1 London, UK.

\section{How to cite this article:}

Madhavi Baiju, S. Sreelekha, R. Shiny, S. S. Veena and Byju, G. 2020. Site Specific Nutrient Management of Cassava Improves Soil Quality. Int.J.Curr.Microbiol.App.Sci. 9(12): 416-424. doi: https://doi.org/10.20546/ijcmas.2020.912.052 